\title{
13. CLAY COMPONENTS OF POST-MIDDLE JURASSIC SEDIMENTS OF THE SOUTHWEST ATLANTIC, DEEP SEA DRILLING PROJECT, LEG 71: DEPOSITIONAL HISTORY AND AUTHIGENIC TRANSFORMATIONS ${ }^{1}$
}

\author{
I. M. Varentsov, B. A. Sakharov, and T. G. Eliseeva, Geological Institute of the U.S.S.R. Academy of Sciences, \\ Moscow, U.S.S.R.
}

\begin{abstract}
To elucidate the main aspects of clay mineral genesis in Leg 71 sediments from the Southwest Atlantic, clay components were studied by X-ray diffraction and geochemical analysis, in the context of lithological and geological data. Four mineral complexes were distinguished.

1) A Late Jurassic to early-middle Albian complex (Site 511) represented mostly by dioctahedral smectite and hydromica admixed with kaolinite, chlorite, and quartz, that may testify to a warm, possibly humid climate in the source area.

2) An early-middle Albian to middle Maestrichtian complex of mixed-layer disordered phases of smectite-mica with an admixture of hydromica (Site 511) that does not permit evaluation of climate in the source area.

3) A late Eocene to early Oligocene complex with dioctahedral smectite admixed with hydromica and traces of chlorite, quartz, and feldspar that suggests a warm, humid climate in the source area.

4) A late Oligocene to Pleistocene mixed-layer disordered phase of smectite-mica (Sites 512-514) that testifies to the climatic deterioration in this area since the end of the Oligocene.

Postsedimentary changes and the role of erosional hiatuses are also examined.
\end{abstract}

\section{INTRODUCTION}

Studies in recent years have shown that detrital clay components of deep sea sediments reflect in their chemi$\mathrm{cal}$ and structural characteristics the climate of their land source areas. In addition, some clay components are sensitive indicators of the volcanogenic and authigenic processes of their synthesis or postsedimentary transformations (Biscaye, 1965; Chester and Aston, 1976; Drits and Koporulin, 1973; Griffin et al., 1968; Jacobs, 1974; Rateev et al., 1968; Shutov et al., 1969; Weaver et al., 1971; Windom, 1976).

One of the main tasks of DSDP Leg 71 was elucidation of the history of sedimentation in the Southwest Atlantic and evaluation of the factors controlling the evolution of the paleoceanographic environments of post-Middle Jurassic sedimentation (Ludwig et al., 1980). It was hoped that study of clay minerals in the context of data on lithology and geochemistry would help answer these questions.

The objectives of this investigation were (a) to study the clay components of the sediments and to establish their genesis; (b) to find out how adequately the clay components reflect climatic changes in the source area; (c) to evaluate the postsedimentary processes of transformation of clay materials; and (d) to determine the role of erosional hiatuses in sedimentation in the alteration of the clay matter.

\section{MATERIALS AND METHODS}

This chapter is based on the study of core materials from DSDP Leg 71 , which were kindly provided by Dr. V. A. Krasheninnikov, Co-

\footnotetext{
${ }^{1}$ Ludwig, W. J., Krasheninnikov, V. A., et al., Init. Repts. DSDP, 71: Washington (U.S. Govt. Printing Office).
}

Chief Scientist of Leg 71. About 600 samples were studied as thin sections under a microscope. The results of this study and shipboard data enabled us to select representative samples for X-ray diffraction. For this purpose colloidal fractions $(<0.001 \mathrm{~mm})$ of the sediment were prepared at the Laboratory of Mechanical Analysis (under the direction of N. V. Rengarten). X-ray diffractometry was performed using a DRON-2 diffractometer (U.S.S.R.) at radiation $\mathrm{CuK} \alpha, 35 \mathrm{kV}$, and $20 \mathrm{~mA}$. The rate of scanning under normal conditions was $2 \% \mathrm{~min}$ and for more detailed study $1 \% \mathrm{~min}$. The diffractograms were obtained for samples that had been airdried, treated with glycerine (the controlled samples were treated with ethylene glycol), and heated at $550^{\circ} \mathrm{C}$. Interpretation of mixed-layer phases and determination of the quantitative relationships of the various types of layers and of the peculiarities of their alternations were based on comparison of the experimental data with diffractograms for the corresponding models (Drits and Sakharov, 1976). The chemical composition of the sediments was determined in the Chemical-Analytical Laboratory of the Institute of Geochemistry of the Siberian Branch of the U.S.S.R. Academy of Sciences, Irkutsk (Dr. V. P. Afonin), by X-ray fluorescent spectroscopy with control by classical bulk analysis.

\section{THE DISTRIBUTION OF CLAY COMPONENTS}

Detailed lithological and geochemical studies of the core samples and survey study of diffractograms enabled us to concentrate upon two key sections, Holes 511 and $513 \mathrm{~A}$, which exhibit rather completely the main sediment types of the Southwest Atlantic.

\section{Hole 511}

The lithologic-mineralogical description of the deposits composing the Site 511 section are given elsewhere in this volume. The most important information about the mineral composition of the size fraction $<0.001 \mathrm{~mm}$ is presented in Figure 1. Some of the representative types of clay minerals are illustrated by diffractograms (Fig. 2). The main complexes of clay minerals are: 


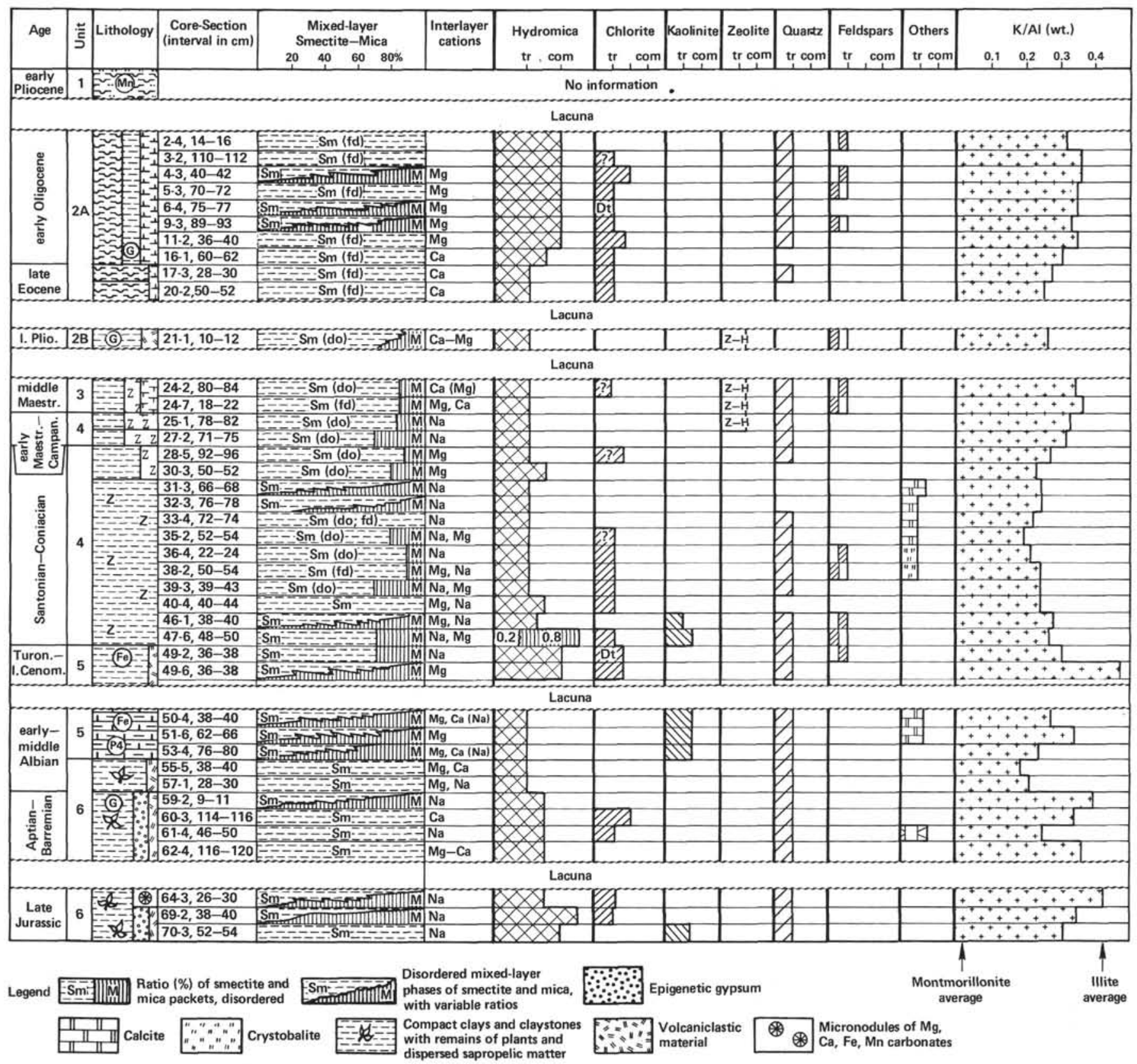

Figure 1. Distribution of clay components (size fraction $<0.001 \mathrm{~mm}$ ) in upper Mesozoic to Cenozoic deposits, Falkland Plateau, Hole 511. The montmorillonite average describes the value of the K/Al ratio in the mean montmorillonite-beidellite (Weaver and Pollard, 1973). (Standard lithological symbols are described in the introduction. Abbreviations for clay minerals: Fe, Fe-hydroxides; G, glauconite; $\mathrm{H}$, heulandite; M, packets of dioctahedral mica; Mn, manganese hydroxides in patches and nodules; Py, pyrite; Sm, dioctahedral smectite; $Z$, zeolite. Other abbreviations: com, common; do, disordered; fd, finely dispersed; tr, trace.)

\section{1) Late Jurassic to early-middle Albian Hydromicaceous-smectitic Complex}

This complex is represented by a significant predominance of two major components: dioctahedral smectite and hydromica with a slight admixture of chlorite, quartz, and kaolinite (see Fig. 2C). These clay minerals are distributed in Unit 6, the Upper Jurassic to lowermiddle Albian, represented by relatively shallow water (shelf), mostly clay sediments with a small admixture of silty particles of glass of medial-acid composition (up to $10 \%$ ) and pyrite-marcasite patches; dispersed sapropel- like organic matter and plant fragments is also characteristically present. The presence of $\mathrm{Ca}$ among the interlayer cations may indicate either a relatively fresh water environment of sediment accumulation or a rather weak reworking of river clay sediments in the zone of mixing with seawater (estuary), accompanied by significant exchange of interlayer cations. Among the monotonously distributed clay minerals an erosional hiatus separates the Late Jurassic sediments from Aptian-Barremian deposits. The sediments lying at the base of this hiatus are represented by a disordered mixed-layer phase (smectite with an appreciable admixture of hydromica and traces 


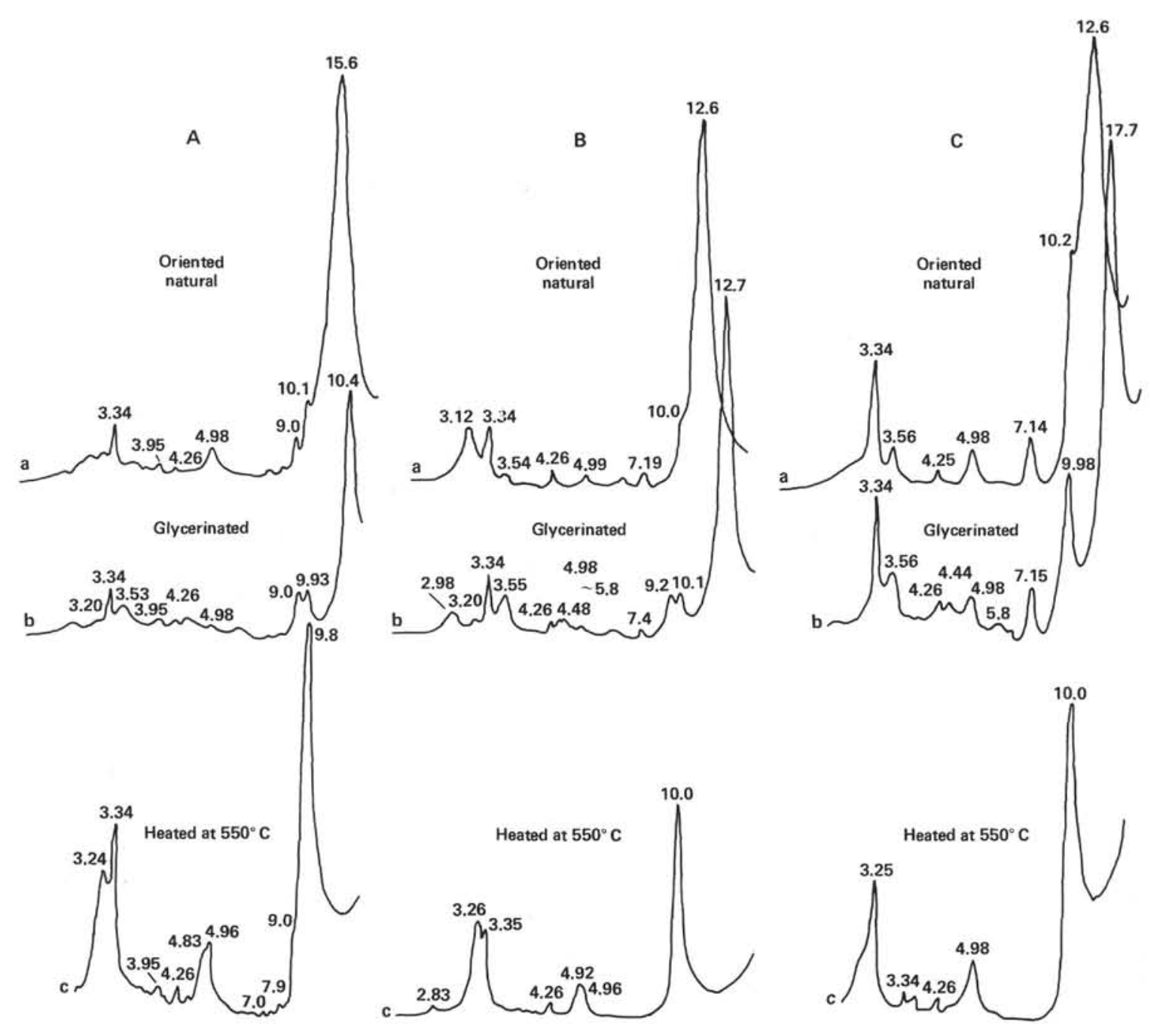

Figure 2. X-ray diffractograms of late Mesozoic and Cenozoic samples (size fraction $<0.001 \mathrm{~mm}$ ), Falkland Plateau, Site 511. Radiation: $\mathrm{CuK} \alpha$. A. Sample 511-24-2, 80-82 cm; finely dispersed, disordered mixed-layer phase of smectite-mica, relationship of packets $\mathrm{W}_{\mathrm{sm}}: \mathrm{W}_{\mathrm{m}}=0.9: 0.1$; admixture of hydromica, zeolite from the heulandite group, and quartz. $\mathrm{B}$. Sample 511-49-2, 36-38 cm; mixed-layer disordered phase of smectite-mica, relationship of packets $\mathrm{W}_{\mathrm{sm}}: \mathrm{W}_{\mathrm{m}}=0.7: 0.3$; admixture of hydromica, defective chlorite, traces of quartz, feldspars. C. Sample 511-70-3, 52-54 cm. Na $=$ dioctahedral smectite, admixture of hydromica, kaolinite, and quartz.

of chlorite; see Fig. 1). A rather sensitive index of the micatization process may be the $\mathrm{K} / \mathrm{Al}$ ratio. Figure $3 \mathrm{C}$ shows that sediments in the zone of erosional contact are characterized by $\mathrm{K} / \mathrm{Al}$ values considerably higher than the average values for the lithological units. In other words, a relatively long chromatographic treatment of sediments in the zone of erosional contact results in much higher saturation of $\mathrm{K}$. This is accompanied by the formation of interlayers of mica in the mixed-layer phase of smectite-mica, with disordered alternations of interlayers of different types.

\section{2) Early-middle Albian to late Cenomanian- Turonian Complex}

This complex is represented by a disordered mixedlayer phase of smectite-mica admixed with hydromica. In the lower part of the interval (lower-middle Albian) there is an appreciable admixture of kaolinite. In the upper part (Turonian-upper Cenomanian), there are perceptible amounts of dioctahedral chlorite. The given complex of clay minerals is rather well developed in Unit 5 , where it is represented by variegated and, in the upper part, red, mostly clayey, nannofossiliferous sediments that contain up to $50-70 \%$ clay matter, dispersed Fe-hydroxides (up to 7\%), and admixtures of medianbasic volcaniclastic material (up to 10\%). According to Sliter (Shipboard Scientific Party, et al., 1977), remains of benthic foraminifers in these deposits testify to the shelf depths of an open marine basin (100 to $400 \mathrm{~m}$ ). At the end of the interval, the basin further expanded and deepened. In the upper part of the interval the clay components are represented by disordered, mixed-layer phase smectite-mica incorporating about $30 \%$ of micaceous interlayers (see Fig. 2B; Fig. 1).

Worth special attention is the obvious micatization of clay matter in the zone of erosional contact: the lowermiddle Albian to upper Cenomanian-Turonian (Fig. 3B). This process manifests itself both in the higher $\mathrm{K}$ / Al values, as compared to the average ones immediately near the contact, and in the presence of rather appreci- 


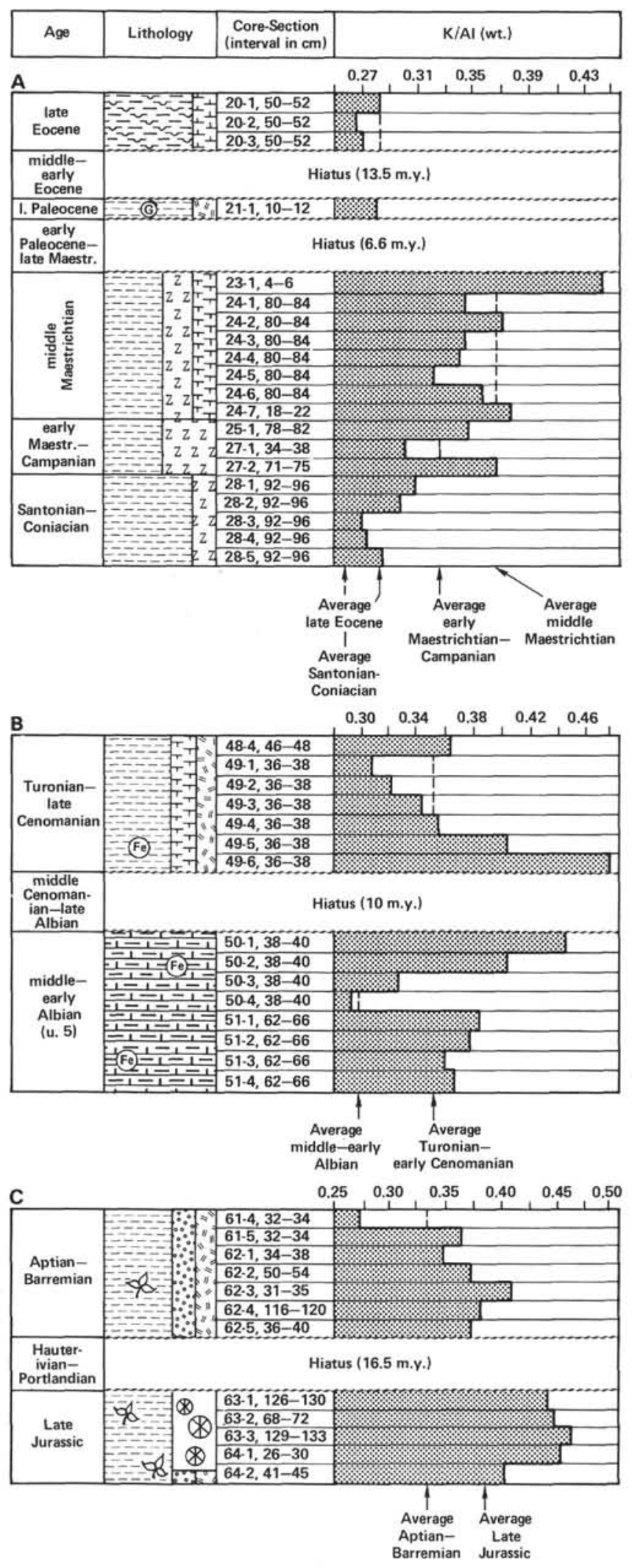

Figure 3. Distribution of $\mathrm{K} / \mathrm{Al}$ values (weight ratios) in Hole 511. A. Middle Maestrichtian, late Paleocene, and late Eocene deposits near the contact with the Mesozoic-Cenozoic stratigraphic hiatus. B. Early-middle Albian (Unit 5) and late Cenomanian-Turonian deposits near the contact with the late Albian to middle Cenomanian hiatus. C. Late Jurassic and Aptian-Barremian deposits near the contact with the Hauterivian-Portlandian hiatus. (Symbols as in Fig. 1.) able amounts of separate phases of hydromica and chlorite (see Fig. 1).

\section{3) The Coniacian-Santonian to Middle Maestrichtian Complex}

This complex is represented mostly by disordered mixed-layer phases of smectite-hydromica. The ratio of the packets $\mathrm{W}_{\mathrm{sm}}: \mathrm{W}_{\mathrm{m}}$ varies from monomineral mica to a mixed-layer mineral with a value of $0.7: 0.3$. There are also insignificant amounts of hydromica and traces of dioctahedral, frequently defective chlorite (see Figs. 1, $2 \mathrm{~A})$. In sediments of the upper part of the interval, considerable amounts of zeolite from the heulandite group developed after heavily altered, fine, volcaniclastic material. On the whole, mostly clay sediments accumulated at that time; however, during the Campanian-early Maestrichtian these sediments included a high content (up to $70 \%$ ) of fine, basic volcaniclastics transformed into zeolites (heulandite). Sedimentation proceeded in an open, relatively deep water (not less than $2000 \mathrm{~m}$ ), oceans ic basin below the carbonate compensation depth, with active, meridionally directed currents (Barker, Dalziel, et al., 1977).

As in the zones already described, erosional hiatuses are well defined by increased hydromicaceous components. A significant increase of the $\mathrm{K} / \mathrm{Al}$ value occurs near the contact between the middle Maestrichtian and late Paleocene (Fig. 3A; and see Fig. 1).

\section{4) Cenozoic Complex of Clay Components}

This complex is represented mainly by finely dispersed dioctahedral smectite, disordered, with rather appreciable amounts of hydromica and with traces of chlorite, quartz, and feldspars (see Fig. 1). The middle part of the lower Oligocene deposits contains mixed-layer phases of mica-smectite in which the relationships of the constituent packets vary. These components are significant constituents of muddy diatomaceous oozes and nannofossildiatomaceous oozes accumulating under deep oceanic conditions and frequently containing terrigenous grains of glauconite.

We had no samples for an adequate characterization of the accumulation of clay components in the late Pliocene-Pleistocene (see Fig. 1).

\section{Hole 513A}

The most important information about the clay components of this section is presented in Figure 4; representative examples of X-ray diffractograms are given in Figure 5. The lithology and mineralogy of the sediments is discussed elsewhere in the volume.

The clay components of a relatively thick section $(379.34 \mathrm{~m})$ of Oligocene-Holocene sediments are characterized by pronounced monotony, despite significant variations in sediment composition and sedimentation conditions (see Fig. 4). The clays mostly consist of a mixture of two components: (1) disordered mixed-layer phase smectite-mica with variable relationships between interlayers of different types and (2) appreciable amounts of hydromica. Dioctahedral chlorite is present as a perceptible admixture, especially in the upper part of the upper Pliocene and in Holocene-Pleistocene sediments; 


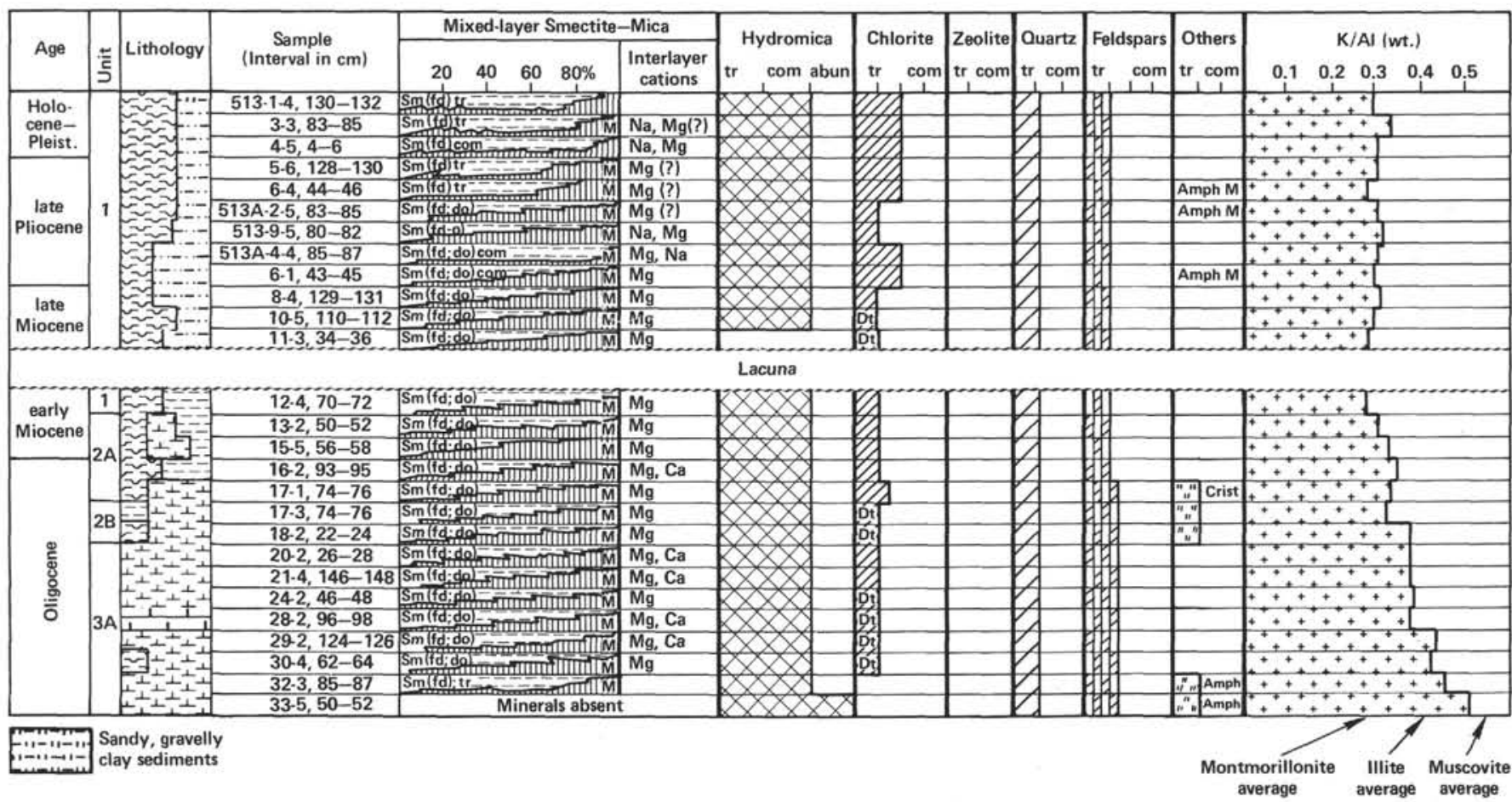

Figure 4. Distribution of clay components (size fraction $<0.001 \mathrm{~mm}$ ) in Cenozoic deposits, Site 513. Basalt basement was reached in Core $513-34$, at 380.5 meters sub-bottom depth. (Standard lithological symbols are described in the Introduction; others are in Fig. 1. Abbreviations for minerals: Amph, amorphous, mostly siliceous matter; M, mica; Sm, smectite interlayers. Other abbreviations: abun, abundant; com, common; $\mathrm{df}$, defective; do, disordered; fd, finely dispersed; tr, trace.)

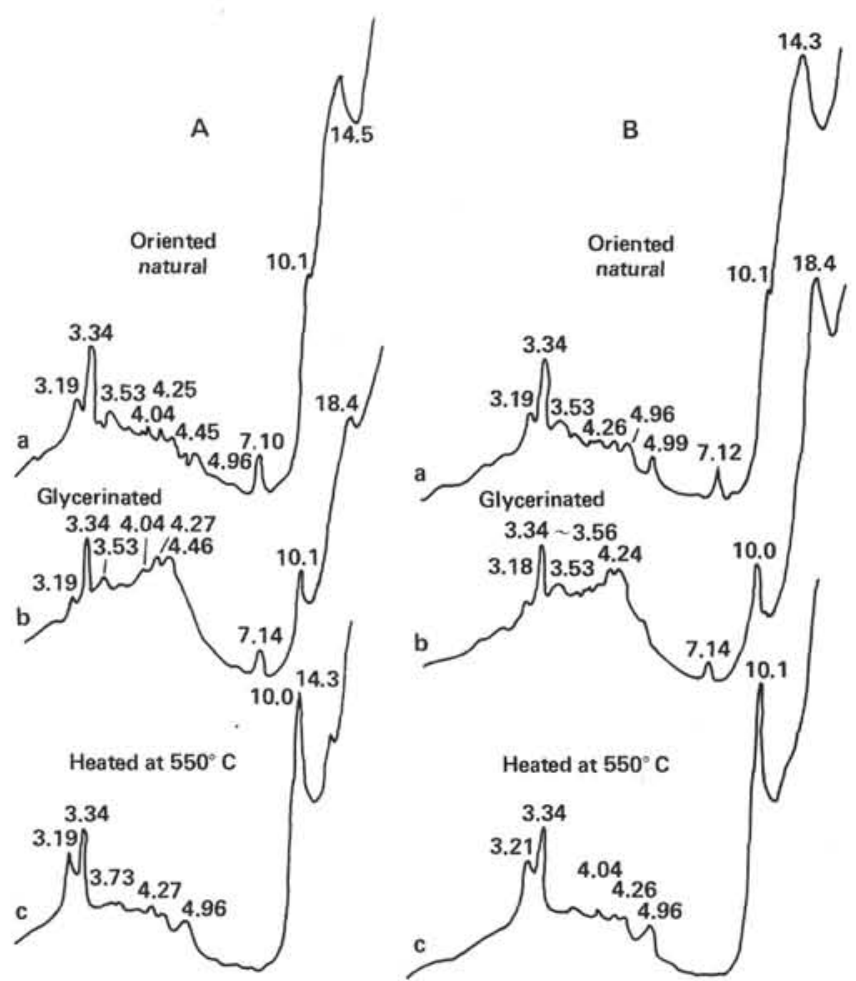

Figure 5. X-ray diffractograms of Cenozoic samples (size fraction $<0.001 \mathrm{~mm}$ ), Site 513. Radiation: CuK $\alpha$. A. Sample 513A-6-1, $43-45 \mathrm{~cm}$. Hydromica, finely-dispersed, disordered, mixed-layer phase of smectite-mica, chlorite, admixture of feldspars, quartz. B. Sample 513A-11-3, 34-36 cm. Hydromica, finely-dispersed, disordered, mixed-layer phase of smectite-mica; defective chlorite; admixture of feldspars, quartz. below are trace amounts of defective chlorite (see Figs. 4-5). An admixture of quartz and feldspars is invariably observed. The Oligocene sediments display traces of crystobalite as a product of postsedimentary changes in biogenic siliceous material. The erosional hiatus separating sediments of the early and late Miocene is clear, owing to high $\mathrm{K} / \mathrm{Al}$ values in the zone of contact (Fig. 6). As noted in the case of Hole 511, a long-term effect of seawater during the erosional hiatus is reflected in an appreciable absorption of $\mathrm{K}$ and in the micatization of smectitic components.

Near the contact with the basalt basement, the clay components of foram-nannofossil oozes (Sample 513A$33-5,50-52 \mathrm{~cm}$; Fig. 4) are represented almost entirely by hydromica. In this sample, the $\mathrm{K} / \mathrm{Al}$ ratio $(0.51)$ reached the value peculiar to muscovite $(0.53$; Brown, 1961). Such a fact can be interpreted as a result of hydrothermal near-contact alteration.

The relative monotony of the composition of the clay components of the section enables us to evaluate the effect of postsedimentary changes, seen in a successive increase of the $\mathrm{K} / \mathrm{Al}$ ratio with depth (see Fig. 4). This can indicate the initial stages in the transformation of smectite into mica.

\section{FACTORS CONTROLLING THE GENESIS OF CLAY COMPONENTS IN POST-MIDDLE JURASSIC SEDIMENTS OF THE SOUTHWEST ATLANTIC}

The clay components of the sedimentary cover of the ocean floor are in many cases carriers of information about the factors controlling the genesis of the sedi- 

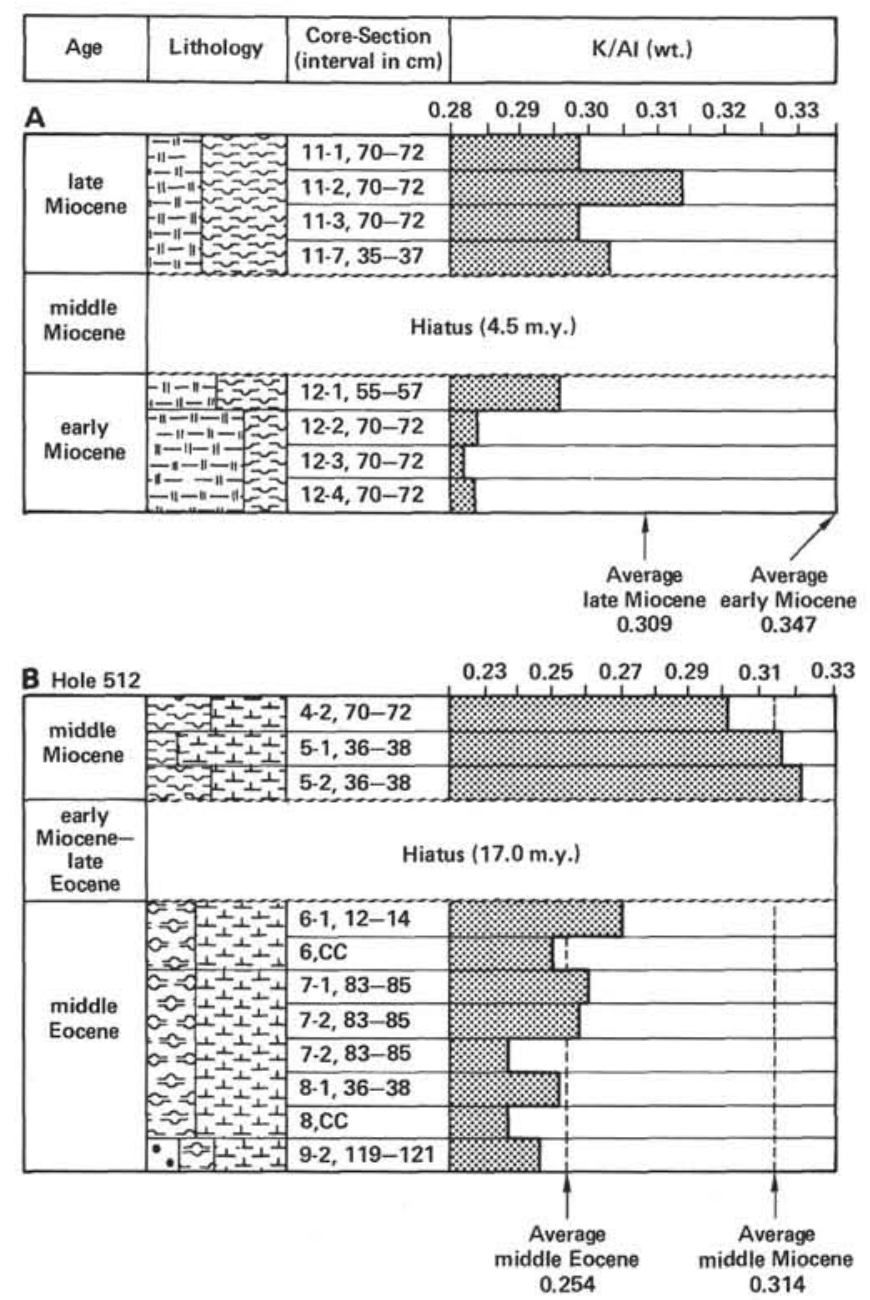

Figure 6. Distribution of $\mathrm{K} / \mathrm{Al}$ values (weight ratios). A. Early and late Miocene deposits near the contact with the middle Miocene stratigraphic hiatus (4.5 m.y.), Site 513. B. Middle Eocene and middle Miocene deposits near the contact with the late Eoceneearly Miocene stratigraphic hiatus (17.0 m.y.), Site 512, presented for comparison.

ments. Clay components accumulated as products of terrigenous runoff can reflect the climatic conditions predominating within the source area. Long interaction with sea water results in initial authigenic transformations of the clay matter. Deep burial in the sedimentary sequences generally causes noticeable transformations in the structure and chemistry of clays. What follows is a brief description of the main factors in the genesis of the clay components of post-middle Jurassic deposits of the Southwest Atlantic.

\section{Clay Minerals as Indicators of Past Climatic Conditions in the Source Area}

Changes in climatic conditions have been rather precisely registered in a regular change of clay mineral complexes in the section of the Falkland Plateau region penetrated by Hole 511 (see Fig. 1). As already shown, shallow-water clay sediments with sapropelic material and fragments of terrestrial plants accumulated during the Late Jurassic to early-middle Albian. The clay matter of the sediments is represented mostly by dioctahedral smectite and hydromica admixed with kaolinite, chlorite, and quartz. The presence of these components may testify to the existence in the drainage system of a warm, possibly humid climate favoring the initial stages of crustal weathering. Spore-pollen assemblages (Kotova, this volume) show that climate on land adjacent to this proto-Atlantic Basin during the Late Jurassic-Early Cretaceous was hot, with humidity increasing toward the middle Albian (Thompson, 1977). Sedimentation under conditions of a stagnant, relatively shallow water (shelf) basin, probably in a low-salinity regime, promoted very little authigenic transformation of clay materials. This may be indicated by the presence of $\mathrm{Ca}$ in the composition of the exchange cations. In this connection we should note the appreciable changes that occur in the chemistry of suspended river clay materials in interacting with sea water. Sulphide contamination in the bottom water and in sediments predetermine to a large extent the course of diagenetic reaction. It has been established that under highly reducing conditions, the presence of considerable concentrations of $\mathrm{S}^{2-}$ ions in interstitial waters can result in the extraction of iron from the structure of smectites, accompanied by deposition of $\mathrm{Fe}$-sulphides and a corresponding enrichment of these clay minerals in $\mathrm{Mg}$ (Heller-Kallai and Rozenson, 1978).

From the early-middle Albian to the late Cenomanian-Turonian, relatively shallow water (shelf) sediments accumulated under open marine conditions. Their clay components are represented by a disordered mixed-layer phase of smectite-mica admixed with hydromica. In this case it is difficult definitely to interpret the mineral composition of the clays so as to characterize the climate prevailing in the source area at that time. Indirect data do not with certainty indicate cooling. The clays indicate postsedimentary transformations under open ocean conditions. This is suggested both by the presence of mixed-layer phases with a particular relationship between smectitic and micaceous packets $\left(\mathrm{W}_{\mathrm{sm}}: \mathrm{W}_{\mathrm{m}} \approx 0.7: 0.3\right)$ and by the appreciable amounts of hydromica and chlorite.

The monotonous composition of clay components actually continues up to the late Paleocene (Fig. 1). The deepening and expansion of the open oceanic basin during the Coniacian-Santonian to the middle Maestrichtian was likely to favor authigenic clay transformations: in the mixed-layer disordered phases of smectite-mica the amount of micaceous packets reaches $30 \%$.

During the late Eocene-early Oligocene, clayey-diatomaceous, clayey-nannofossil, and diatomaceous sediments accumulated. They exhibit appreciable amounts of finely dispersed dioctahedral smectite, disordered and with an admixture of hydromica and traces of chlorite, quartz, and feldspars. The clay compositions suggest relatively warm, humid climates within the source area. The study of planktonic foraminiferal remains, oxygen isotope data, and spore-pollen assemblages (Bratseva, this volume) confirm this conclusion. The rather young age of the deposits, their insignificant thickness, and the relatively low values of the heat flow (see site chapters) contributed insignificantly to postsedimenta- 
tion changes. It was shown earlier that the $\mathrm{K} / \mathrm{Al}$ value correlates rather well with the amounts of the micaceous packets in mixed-layer phases of smectite-mica and with the presence of hydromica (see Figs. 1, 4), minerals that are essential components of the late Tertiary deposits. An abrupt deterioration, a climatic cooling at the end of the late Oligocene (Boltovskoy, 1980; Ciesielski and Wise, 1977) manifested itself regionally in the accumulation of mostly mixed-layer-phase smectite-mica on through the Holocene, in sediments of all sites (512514; Fig. 7). Investigations carried out by Jacobs (1974) in the Atlantic sector of the Arctic Basin established that the composition of clay minerals along with terrigenous components definitely reflects climatic conditions over the source area in the second half of the Cenozoic. Jacobs emphasizes the importance as an indicator of illite crystallinity under warm, humid, climatic conditions (Eocene, Oligocene) and the predominance of mechanical weathering with the formation of clastic illite preserving good crystallinity since the Miocene and later, under relatively cold climatic conditions. Having noted that $\mathrm{K}$ and $\mathrm{Mg}$ of seawater promotes the formation of illite and chlorite at the expense of montmorillonite, Jacobs (1974) believes that under antarctic conditions diagenetic changes for the late Tertiary sediments are negligible compared to the climatic effects.

\section{Postsedimentary Alterations of Clay Components}

In analyzing the relative contribution of climatic factors in transforming clay components, special importance was attached to the influence of postsedimentary processes. Such an influence was distinctly manifested by the presence of relatively high amounts of mica packets (up to $30 \%$ ) in the disordered phases of smectite-mica that prevail in sediments from the early-middle Albian to the middle Maestrichtian of the Falkland Plateau. However, the pattern observed is also complicated by the influence of rather long erosional hiatuses promoting the authigenic alteration of clay matter. The most pronounced pattern of change in the rather uniform complex of clay components, represented mostly by the disordered mixed-layer smectite-mica with varying quantitative relationships among the interlayers and considerable amounts of hydromica and chlorite, was observed in the section at Site 513 (see Figs. 4, 7). Sediments of this section exhibit a pronounced increase of $\mathrm{K} / \mathrm{Al}$ values with depth (see Fig. 4). In the lower beds of nannofossil sediments near the contact with the basement basalts the clay components are wholly represented by hydromica in which the $\mathrm{K} / \mathrm{Al}$ value $(0.51)$ is rather close to that of muscovite $(0.53)$ (Brown, 1961). In interpreting this fact it should be borne in mind that Site 513 was drilled on the western flank of the Mid-Atlantic Ridge, the age of the basalt basement being approximately 37.5 $\mathrm{Ma}$ (early Oligocene). Similar structures of the ocean floor are characterized by relatively higher heat flow values and possible hydrothermal exhalations favoring authigenic alterations of clays.

Thus the postsedimentary transformations of clay matter observed in post-Middle Jurassic deposits manifest themselves mostly at various stages of the process of micatization of smectite material. Some authors have considered the mechanics of the transformation of smectite to mica in the processes of post-sedimentary alterations and have shown that the transformation proceeds through the formation of mixed-layer phases with an increasing content of mica interlayers (Drits and Koporulin, 1973; Pollard, 1971; Shutov et al., 1969; Weaver et al., 1971). The initial stages in the transformation of montmorillonite take place within the interlayer space in which potassium and other cations accumulate. The supply and intermediate accumulation of $\mathrm{Al}$ at the expense of $\mathrm{Si}$ and the transformation of tetrahedral layers proceed through the interlayer space (Pollard, 1971).

\section{The Role of Erosional Hiatuses in Transformation of Clay Matter}

Post-Middle Jurassic sedimentation in the Southwest Atlantic is characterized by many long erosional hiatuses (Figs. 1, 4, 7). As earlier shown (see Figs. 3, 6), the clay components occurring immediately near the erosional contacts are characterized by higher values of $\mathrm{K} / \mathrm{Al}$, compared to the average values of this ratio within sedimentary units. The changes result not only from the relative accumulation of residual clay products arising from the dissolution of low-resistant carbonate and siliceous components of the sediment. The long-term influence of seawater, resulting in the formation of hydromicaceous and chlorite components, is also significant. Experimental studies by Sayles and Mangelsdorf (1977), carried out at room temperature and normal pressure, showed that when river clay sediments (mainly smectite and hydromica) were mixed with seawater, the following ion-exchange sorptions took place (in $\%$ of exchangeable cations): $\mathrm{Na}^{+}$about $50 \%, \mathrm{Mg}^{2+}$ up to $40 \%$, and $\mathrm{K}^{+}$up to $17 \%$. However, when the temperature was decreased from 21 to $2^{\circ} \mathrm{C}$, the achieved equilibrium sorption of cations changed. Judging from other authors (Mangelsdorf et al., 1969; Bishoff et al., 1970; Sayles et al., 1973), at a deep-sea bottom-water temperature of $2^{\circ} \mathrm{C}$, the sorption would be $15 \%$ for $\mathrm{Na}^{+}$and $10 \%$ for $\mathrm{K}^{+}$, accompanied by substitutions of $3 \%$ of the $\mathrm{Ca}^{2+}$ and $25 \%$ of the $\mathrm{Mg}^{2+}$.

Along with the authigenic formation of micaceous and chlorite components, an appreciable accumulation of $\mathrm{Fe}, \mathrm{Mn}$ hydroxides, and compounds of titanium and phosphorus was observed in the zones of erosional contacts (Varentsov, this volume).

\section{CONCLUSION}

The study of clay components (size fraction $<0.001$ $\mathrm{mm}$ ) of post-Middle Jurassic deposits of the Southwest Atlantic by X-ray diffractometry and geochemical data on the major components, considered in the context of lithological and geological information, enables us to elucidate the main aspects of the genesis of the minerals.

\section{Clay Minerals as Indicators of Climate in the Source Area}

A number of complexes of clay minerals are distinguished in post-Middle Jurassic deposits within the Falkland Plateau region (Site 511):

a) Late Jurassic to early-middle Albian, represented mostly by dioctahedral smectite and hydromica admixed 


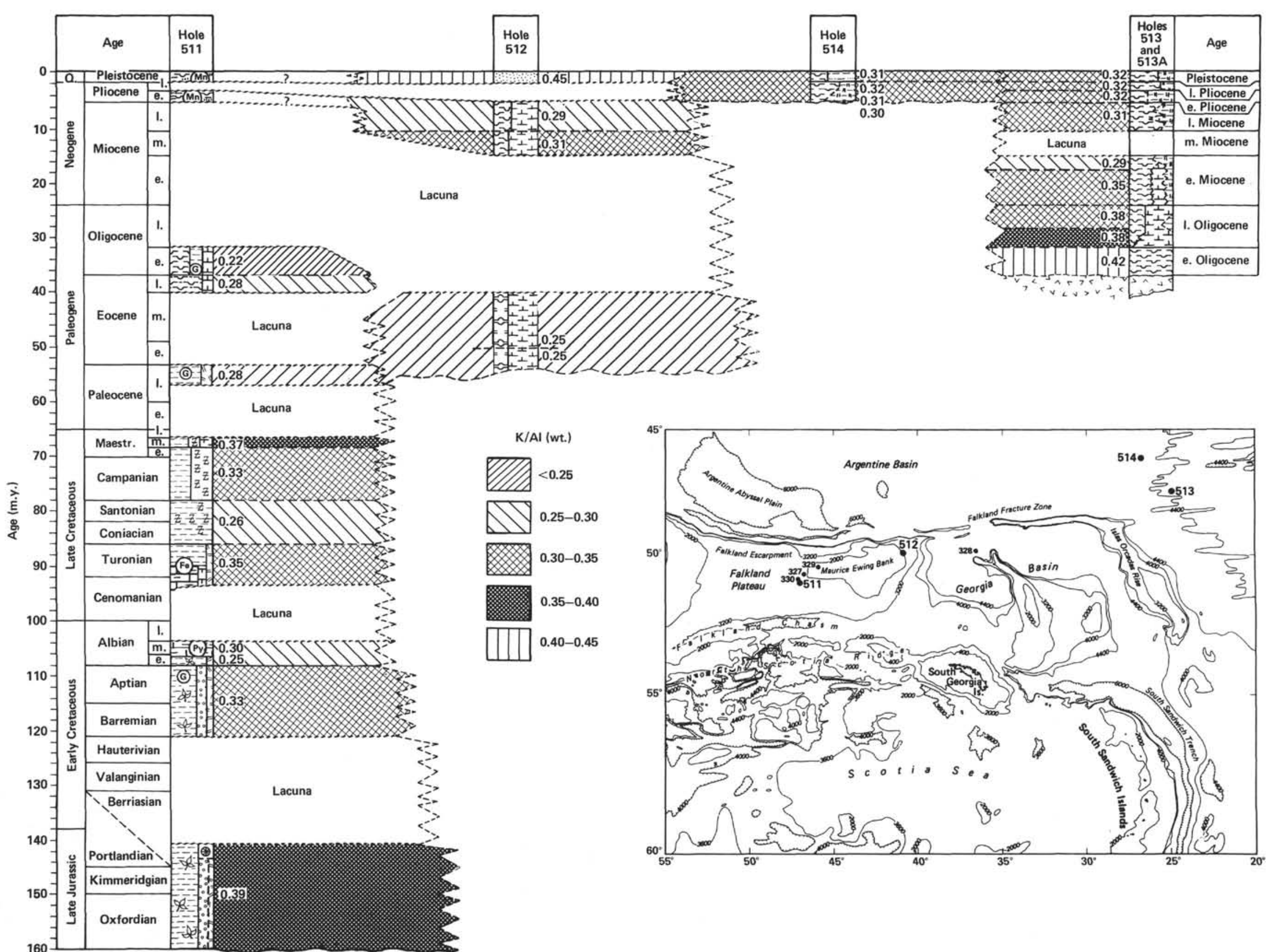

Figure 7. Distribution of average $\mathrm{K} / \mathrm{Al}$ values (weight ratios) in Mesozoic and Cenozoic deposits of the Southwest Atlantic, Leg 71. (Lithological symbols as in Fig. 1.) 
with kaolinite, chlorite, and quartz. The presence of these components may testify to a warm climate in the drainage systems, with humidity increasing toward the Albian. This conclusion is confirmed by spore-pollen assemblages in the sediments.

b) The second half of the early-middle Albian to the middle Maestrichtian is characterized by the predominance of mixed-layer disordered phases of smectitemica admixed with hydromica. The sediments accumulated under open marine conditions. The clay mineral complex is uninformative about the climate of the source area of that time, because of pronounced authigenic changes.

c) During the late Eocene to early Oligocene there accumulated sediments with appreciable amounts of finely dispersed, disordered dioctahedral smectite with an admixture of hydromica and traces of chlorite, quartz, and feldspars. The composition of the clay components testifies to a humid climate at that time within the source area.

d) In other sites (Holes 512-514), the late Oligocene to Pleistocene deposits contain a mixed-layer disordered phase of smectite-mica with an admixture of hydromica and chlorite. This can be interpreted as evidence of a significant deterioration of climate since the late Oligocene.

\section{Postsedimentary Changes of Clay Components}

The most distinct change in the clays was recorded at Site 513 . The clay components are represented by a disordered mixed-layer phase of smectite-mica with variable quantitative relationships among interlayers of different types and appreciable amounts of hydromica and chlorite; an increase of the $\mathrm{K} / \mathrm{Al}$ value with depth is observed. This fact may indicate a relative intensification of micatization.

\section{The Role of Erosional Hiatuses in Alteration of Clay Matter}

The clay components occurring near erosional contacts are characterized by higher $\mathrm{K} / \mathrm{Al}$ values, compared to the average values for the lithologic units. Along with the formation of micaceous and chlorite components at erosional hiatuses, increased accumulation of $\mathrm{Ti}, \mathrm{Fe}$, $\mathrm{Mn}$, and $\mathrm{P}$ compounds was observed.

\section{ACKNOWLEDGMENTS}

The authors express deep gratitude to their colleagues at the Geological Institute of the U.S.S.R. Academy of Sciences: N. I. Kartoshkina and N. Y. Vlasova, for their help in the processing of analytical data, preparation of core materials, and analysis; N. V. Rengarten for the control in mechanical analysis of sediments; V. A. Krasheninnikov for the core material and for consultation on stratigraphy; V.S. Zelinsky, E. I. Pyatigorskaya, and N. K. Mirskaya for assistance in drafting; G. N. Surovtseva for translation of the paper into English; and V. P. Afonin (Irkutsk Institute of Geochemistry, Siberian Branch of the U.S.S.R. Academy of Sciences) for thorough control of chemical analyses. The critical review of the paper and comments by N. G. Brodskaya and A. G. Kossovskaya improved the work.

\section{REFERENCES}

Biscaye, P. E., 1965. Mineralogy and sedimentation of recent deep-sea clay in the Atlantic Ocean and adjacent seas and oceans. Geol. Soc. Am. Bull., 76:803-832.
Bishoff, J. L., Greek, R. E., and Luistro, A. O., 1970. Composition of interstitial waters of marine sediments: Temperature of squeezing effect. Science, 167:1245-1246.

Boltovskoy, E., 1980. The age of the Drake Passage. Alcheringa, 4(3-4):289-297.

Brown, G. (Ed.), 1961. The X-ray Identification and Crystal Structures of Clay Minerals: London (Mineralogical Society [Clay Minerals Group]).

Chester, R. and Aston, S. A., 1976. The geochemistry of deep-sea sediments. In Riley, J. P., and Chester, R., (Eds.), Chemical Oceanography (Vol. 6): London (Academic Press), 281-390.

Ciesielski, P. and Wise, S. W., 1977. Geologic history of the Maurice Ewing Bank of the Falkland Plateau (Southwestern Atlantic sector of the Southern Ocean) based on piston and drill cores. Mar. Geol., 25:175-207.

Drits, V. A., and Koporulin, V. I., 1973. On postsedimentary transformation of montmorillonite into hydromica. Lithol. Miner. Resour., (Engl. Transl.) 5:145-148.

Drits, V. A., and Sakharov, B. A., 1976. X-ray structural analysis of mixed layer minerals. Trans. Geol. Inst. AN SSSR, 295:325.

Griffin, J. J., Windom, H., and Goldberg, E. D., 1968. The distribution of clay minerals in the World Ocean. Deep-Sea Res., 15: 433-459.

Heller-Kallai, L., and Rozenson, I., 1978. Removal of magnesium from interstitial waters in reducing environments-the problem reconsidered. Geochim. Cosmochim. Acta, 42:1907-1909.

Jacobs, M. B., 1974. Clay mineral changes in Antarctic deep-sea sediments and Cenozoic climatic events. J. Sediment. Petrol., 44(4): 1079-1086.

Ludwig, W. J., Krasheninnikov, V. A., Basov, I. A., et al., 1980. Tertiary and Cretaceous paleoenvironments in the Southwest Atlantic Ocean: Preliminary results of Deep Sea Drilling Project, Leg 71, Geol. Soc. Am. Bull., 91(no. 11):655-664.

Mangelsdorf, P. C., Jr., Wilson, T. R. S., and Daniell, E., 1969. Potassium enrichments in interstitial waters of recent marine sediments. Science, 165:171-174.

Pollard, C. O., Jr., 1971. Appendix: Semidisplacive mechanism for diagenetic alteration of montmorillonite layers to illite layers. In Weaver, C. E., Beck, K. C., Pollard, C. O., Jr., Clay Water Diagenesis during Burial: How Mud Becomes Gneiss. Geol. Soc. Am. Spec. Pap. 134:79-93.

Rateev, M. A., Gorbunova, Z. N., Lisitzyn, A. P., and Nosov, G. I., 1968. Climatic zoning of clay mineral distribution in sediments of the World Ocean. Oceanological Investigations (U.S.S.R. Academy of Sciences, Institute of Oceanology), No. 18.

Sayles, F. L., Manheim, F. T., and Waterman, L. S., 1973. Interstitial water studies on small core samples, Leg 15. In Heezen, B. C., MacGregor, I. D., et al., Init. Repts. DSDP, 20: Washington (U.S. Govt. Printing Office), 783-804.

Sayles, F. L., and Mangelsdorf, P. S., Jr., 1977. The equilibration of clay minerals with sea water: Exchange reactions. Geochim. Cosmochim. Acta, 41:951-960.

Shutov, V. D., Drits, V. A., and Sakharov, B. A., 1969. On the mechanism of postsedimentary transformation of montmorillonite into hydromica. Proc. Int. Clay Conf., 1:523-533.

Shipboard Scientific Party, Harris, W., and Sliter, w. V., 1977. Evolution of the Southwestern Atlantic Ocean basin: Results of Leg 36, Deep Sea Drilling Project. In Barker, P. F., Dalziel, I. W. D., et al., Init. Repts. DSDP, 36: Washington (U.S. Govt. Printing Office), 993-1014.

Thompson, R. W., 1977. Mesozoic sedimentation on the Eastern Falkland Plateau. In Barker, P. F., Dalziel, I. W. D., et al., Init. Repts. DSDP, 36: Washington (U.S. Govt. Printing Office), 877-891.

Turekian, K. K., and Wedepohl, K. H., 1961. Distribution of the elements in some major units of the Earth's crust. Geol. Soc. Am. Bull., 72:175-192.

Weaver, C. E., Beck, K. C., and Pollard, L. D., Jr., 1971. Clay water diagenesis during Burial: How Mud Becomes Gneiss. Geol. Soc. Am. Spec. Pap. 134.

Weaver, C. E., and Pollard, L. D., 1973. The Chemistry of Clay Minerals. Dev. Sedimentol. 15: Amsterdam (Elsevier).

Windom, H. L., 1976. Lithogenous material in marine sediments. In Riley, J. P., and Chester, R. (Eds.), Chemical Oceanography (Vol. 6): London (Academic Press), 103-135. 